\title{
Natural Killer Immunotherapy for Minimal Residual Disease Eradication Following Allogeneic Hematopoietic Stem Cell Transplantation in Acute Myeloid Leukemia
}

\author{
Norimichi Hattori * (D) and Tsuyoshi Nakamaki \\ Division of Hematology, Department of Medicine, Showa University School of Medicine, Tokyo 142-8555, Japan; \\ nakamaki@med.showa-u.ac.jp \\ * Correspondence: nhattor@med.showa-u.ac.jp; Tel.: +81-3-3784-8338
}

Received: 5 April 2019; Accepted: 23 April 2019; Published: 26 April 2019

\begin{abstract}
The most common cause of death in patients with acute myeloid leukemia (AML) who receive allogeneic hematopoietic stem cell transplantation (allo-HSCT) is AML relapse. Therefore, additive therapies post allo-HSCT have significant potential to prevent relapse. Natural killer (NK)-cell-based immunotherapies can be incorporated into the therapeutic armamentarium for the eradication of AML cells post allo-HSCT. In recent studies, NK cell-based immunotherapies, the use of adoptive NK cells, NK cells in combination with cytokines, immune checkpoint inhibitors, bispecific and trispecific killer cell engagers, and chimeric antigen receptor-engineered NK cells have all shown antitumor activity in AML patients. In this review, we will discuss the current strategies with these NK cell-based immunotherapies as possible therapies to cure AML patients post allo-HSCT. Additionally, we will discuss various means of immune escape in order to further understand the mechanism of NK cell-based immunotherapies against AML.
\end{abstract}

Keywords: natural killer cell; immunotherapy; allogeneic hematopoietic stem cell transplantation; acute myeloid leukemia; immune checkpoint; bispecific and trispecific killer cell engagers; chimeric antigen receptors

\section{Introduction}

Allogeneic hematopoietic stem cell transplantation (allo-HSCT) has been recognized as the only curative therapy for patients with acute myeloid leukemia (AML). Allo-HSCT's mode of action is primarily attributed to the graft-versus-leukemia (GVL) effect mediated by donor T-cells and natural killer (NK) cells. However, approximately $40 \%$ of the AML patients who undergo allo-HSCT will relapse, and the two-year post relapse survival among these patients is less than $20 \%$ [1-6]. With the use of targeted sequencing or flow cytometry, the persistent detection of minimal residual disease (MRD) is associated with post-transplantation relapse [7-9]. It is therefore important to provide additional therapies to eliminate MRD after allo-HSCT, particularly in high-risk AML. Donor lymphocyte infusion (DLI) or repeat allo-HSCT as a donor cell-based therapy has been associated with improved survival in patients who relapse after allo-HSCT $[1-3,5,10]$. Although the efficacy of therapeutic DLI in relapsed AML may be suboptimal, pre-emptive, or prophylactic, DLI may have an important role [5,11-13]. Use of the hypomethylating agent azacitidine appears to be effective in AML following allo-HSCT [14,15]. Additionally, pre-emptive treatment with azacitidine may prevent a relapse while monitoring for MRD (NCT01462578) [16].

Previously, it had been presumed that most additional therapies would not be able to suppress the proliferation of leukemia cells in the long term in relapsed AML after allo-HSCT. However, 
the early use of these therapies might prevent relapse in AML, and could be an important step toward improving prognosis. Recently, immunotherapies, including NK cells administration and immune checkpoint inhibitors (ICIs), have been reported as new treatment modalities after allo-HSCT in hematologic malignancies [17-23]. Previous studies had demonstrated that ICIs had antitumor immune responses for several solid tumors and hematologic malignancies [24-26]. However, their responses remained limited because of the lack of MHC classes I and II, which leads to less T-cell activation and proliferation, and is observed in ICI-resistant tumors [27-29]. In contrast, while NK cells express limited MHC (e.g., human leukocyte antigen (HLA)-Bw4, C1, and C2)-dependent receptors, they express non-MHC-dependent receptors including NKG2D, natural cytotoxicity receptors, CD96, T-cell immunoreceptor with Ig, and immunoreceptor tyrosine-based inhibition motif domains (TIGIT), DNAM-1, SLAMF6 (also known as NTB-A), NKRP1-B, and 2B4 [21,30,31]. Additionally, consistent with donor T-cell mediated GVL, donor T-cells' contribution to graft versus host disease (GVHD) is dependent upon recognition of HLA disparities following allo-HSCT. While administration of some ICIs post allo-HSCT may lead to severe GVHD [17,24], donor NK cells confer alloreactivity against tumors without GVHD [32,33]. Recently, we have noted that high NK cell levels in the bone marrow microenvironment immediately following allo-HSCT were associated with better overall survival (OS) and progression-free survival [34]. Moreover, AML patients with lower TIGIT expression following allo-HSCT had superior OS and progression-free survival [35]. Therefore, strategies to activate NK cells in order to reinforce GVL effect as a pre-emptive or prophylactic immunotherapy may improve MRD clearance in high-risk AML after allo-HSCT (Figure 1). In this review, we focus on NK cell-based immunotherapies following allo-HSCT and explore emerging therapies to eradicate MRD.

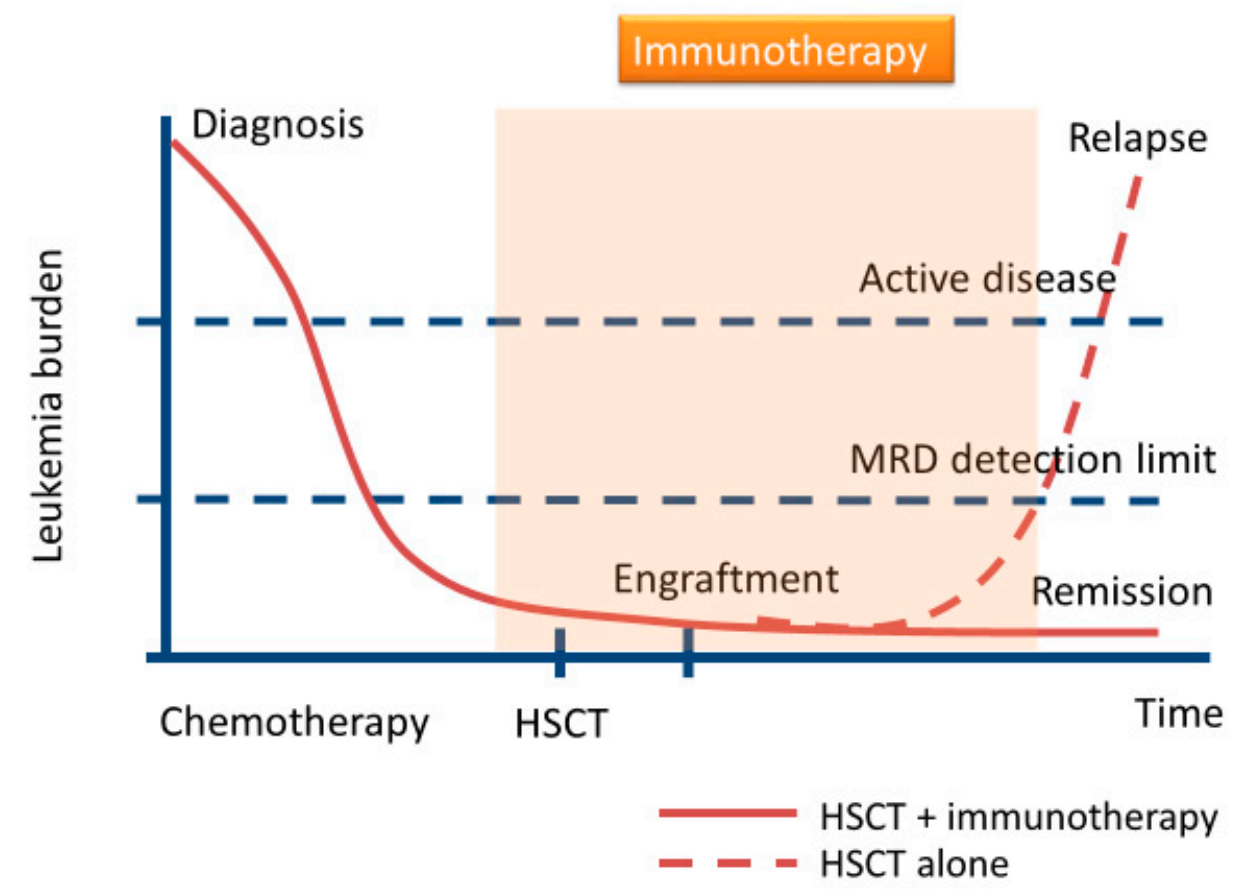

Figure 1. Schematic diagram of immunotherapies for minimal residual disease (MRD) eradication after allogeneic hematopoietic stem cell transplantation (allo-HSCT) in acute myeloid leukemia (AML). Some patients with AML after conventional allo-HSCT will relapse. For the prevention of relapse, immunotherapies may play an important role in the elimination of MRD.

\section{Adoptive NK Cell Therapy and Cytokine-Based NK Cell Therapy}

Previous studies have reported an association between clinical outcomes and NK cell recovery after allo-HSCT. This likely occurs because NK cells play an essential role in GVL effects and also in preventing infection following allo-HSCT $[34,36,37]$. To date, adoptive transfer of NK cells from 
allogeneic donors to patients with AML has been performed following allo-HSCT [38-44]. Additionally, NK cell infusion has been combined with the administration of IL-2 to boost in vivo expansion (Figure 2) [45-48]. T-regulatory cells (Tregs) are significantly increased in number following NK cell infusion and IL-2 administration, which may inhibit NK cell functionality and hinder the efficacy of adoptively transferred NK cells (Figure 3). In cases with prior IL-2-diphtheria toxin fusion protein treatment for the depletion of host Tregs, increased in vivo expansion of NK cells was noted, and relapsed/refractory AML patients were able to achieve complete remission (CR) (NCT00274846 and NCT01106950) [47]. Besides IL-2 administration, NK cells activated by IL-12, IL-15, IL-18, and IL-21 have enhanced antitumor functionality [49-52]. These cytokines also lead to an increase in varying degrees of host and/or donor $\mathrm{CD} 8^{+} \mathrm{T}$-cells. Therefore, these therapies may result in adverse events, including severe GVHD. However, previous studies have demonstrated that adoptively transferred NK cells activated by these cytokines had GVL effect without life-threatening GVHD [49-52]. IL-15/IL-15Ra-Fc (ALT-803) therapy (NCT01885897), for instance, promoted an increase in CD8 ${ }^{+}$T-cells of the effector or effector memory phenotype without increasing Tregs, and no patient developed severe GVHD despite the induction of $\mathrm{CD} 8^{+} \mathrm{T}$-cell activation [51]. One possible reason may be that the preferential expansion of NK cells mediates a reduction of GVHD by inhibiting $\mathrm{CD}^{+}$donor T-cell proliferation [53]. Although adoptive transfer of NK cells during allo-HSCT may be a promising therapy for AML, further studies are required in order to design protocols that balance the persistence of donor NK cells and host/donor T-cell activation. These studies must include the timing of transferred NK cells, NK cell dosage, combination with cytokines, the conditioning regimen, donor selection, and GVHD prophylaxis.

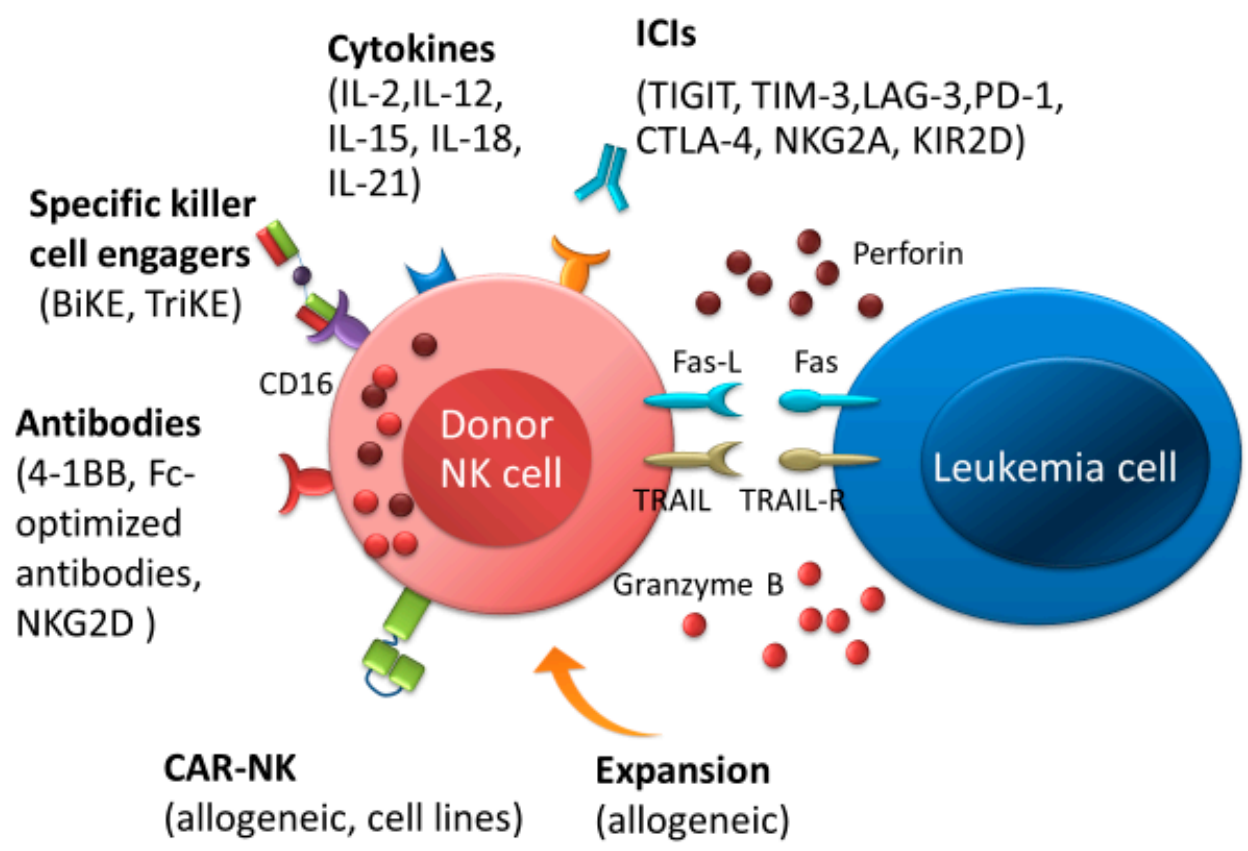

Figure 2. Natural killer (NK) cell immunotherapies after allo-HSCT therapeutic approaches for the elimination of AML. NK cells-based immunotherapeutic concepts are based on stimulating NK cells by cytokines or immune checkpoint inhibitors, promoting antibody-dependent T-cell-mediated cytotoxicity by antibodies or bispecific and trispecific killer cell engagers, and improving NK cell responses by adoptive transfer of NK cells, such as allogenic NK cells or chimeric antigen receptor NK cells. Abbreviations: ICIs, immune checkpoint inhibitors; BiKEs, bispecific killer cell engagers; TriKEs; trispecific killer cell engagers; CAR, chimeric antigen receptor. 


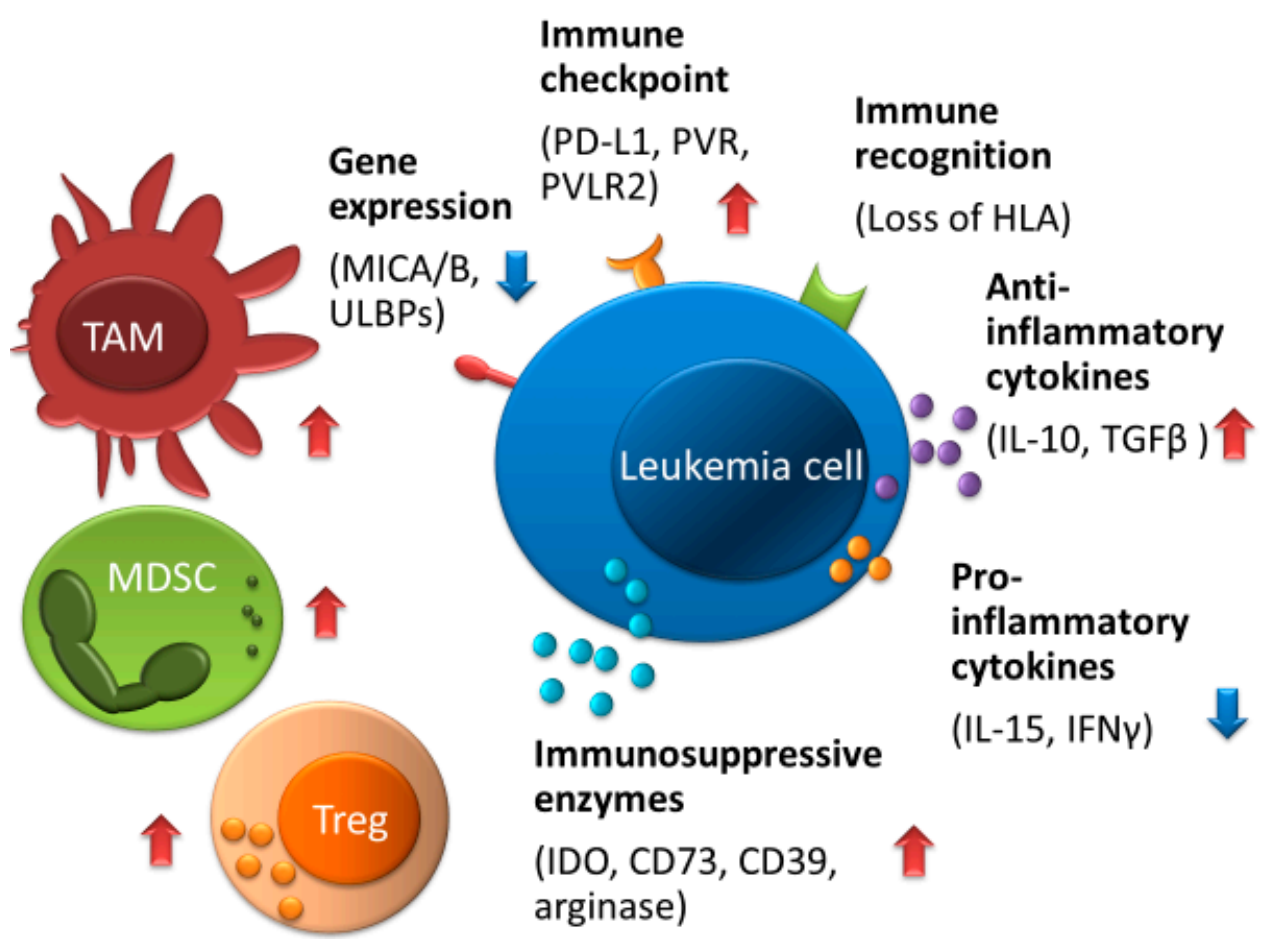

Figure 3. Mechanisms of immune escape against NK cells in AML. The tumor microenvironment consisted of Tregs, TAMs, and MDSCs which can interfere with the function of NK cells, and its microenvironment is increased by anti-inflammatory cytokine including TGF- $\beta$, IL-4, and IL-10 and is decreased by pro-inflammatory cytokines including IFN- $\gamma$ and IL-15. Leukemia cells can produce the metabolic enzymes such as IDO, arginase, CD39, and CD73, which reduce NK cell activity. Upregulation of immune checkpoint molecules including PD-L1, PVR, and PVLR2, low expression of NKG2D ligands such as MICA/B and ULBPs, or impaired expression of HLA can contribute to evading immune surveillance by NK cells. Abbreviations: TAM, tumor-associated macrophages; MDSCs, myeloid-derived suppressor cells; Tregs, regulatory T-cells. Red arrows indicate increased expression, enzymes, cytokine production, and cell proliferation; blue arrows indicate decreased expression and cytokine production.

\section{ICIs for Intensifying the Activation of NK Cells}

NK cells express various co-inhibitory receptors, including killer immunoglobulin-like receptors (KIRs), NKG2A, programmed cell death protein 1 (PD-1), cytotoxic T-lymphocyte-associated protein 4 (CTLA-4), T-cell immunoglobulin, and mucin domain-containing protein 3 (TIM-3), TIGIT, and lymphocyte activation gene 3 (LAG-3). These receptors have recently been recognized as immune checkpoints (Figures 2 and 4). T-cells also express these immune checkpoints in which PD-1, CTLA-4, LAG-3, and B- and T-lymphocyte attenuator (BTLA) had greater expression than in NK cells (Figure 5) [54,55]. In order to block a receptor's inhibitory signal, NK cell activation and leukemia cell killing are induced by a cognate ligand by ICIs. Therefore, administration of ICIs in the first few months post allo-HSCT might be a powerful tool for eradicating MRD following AML. Several clinical trials for ICIs as monotherapy or as part of combination treatment for AML after allo-HSCT have been reported recently [17,20,24,56-58]. CTLA-4 (e.g., ipilimumab) and PD-1 (e.g., nivolumab) blockade have been administered following allo-HSCT in several hematologic malignancies, and beneficial GVL responses have been achieved. However, serious immune-related adverse events and/or severe GVHD were accompanied by exposure to these two ICIs [59]. This might explain how increased donor-derived alloreactive T-cells might cause life-threatening GVHD [57,58]. It would be interesting to test whether NK cell-specific ICIs might enhance anti-leukemia activity without aggravating GVHD more than CTLA-4 or PD-1 blockade. 


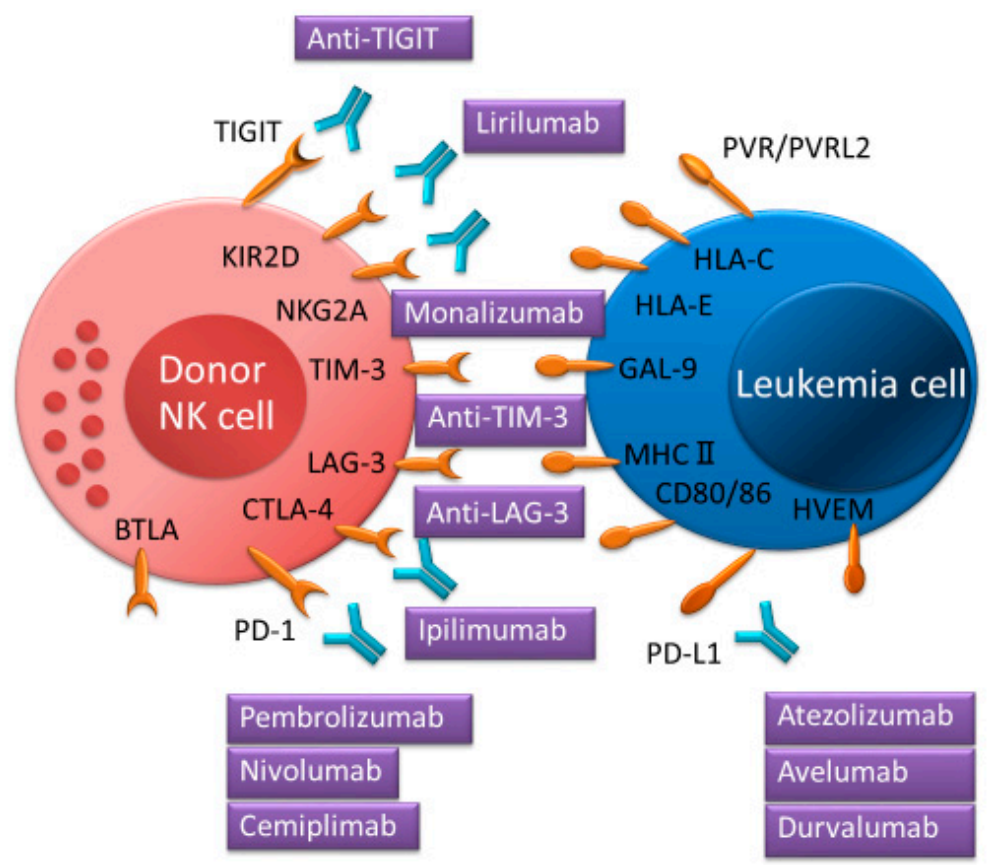

Figure 4. Immune checkpoint inhibitors for targeted NK cell proteins and interactions between immune checkpoint receptors and ligands enhancing NK cell function.
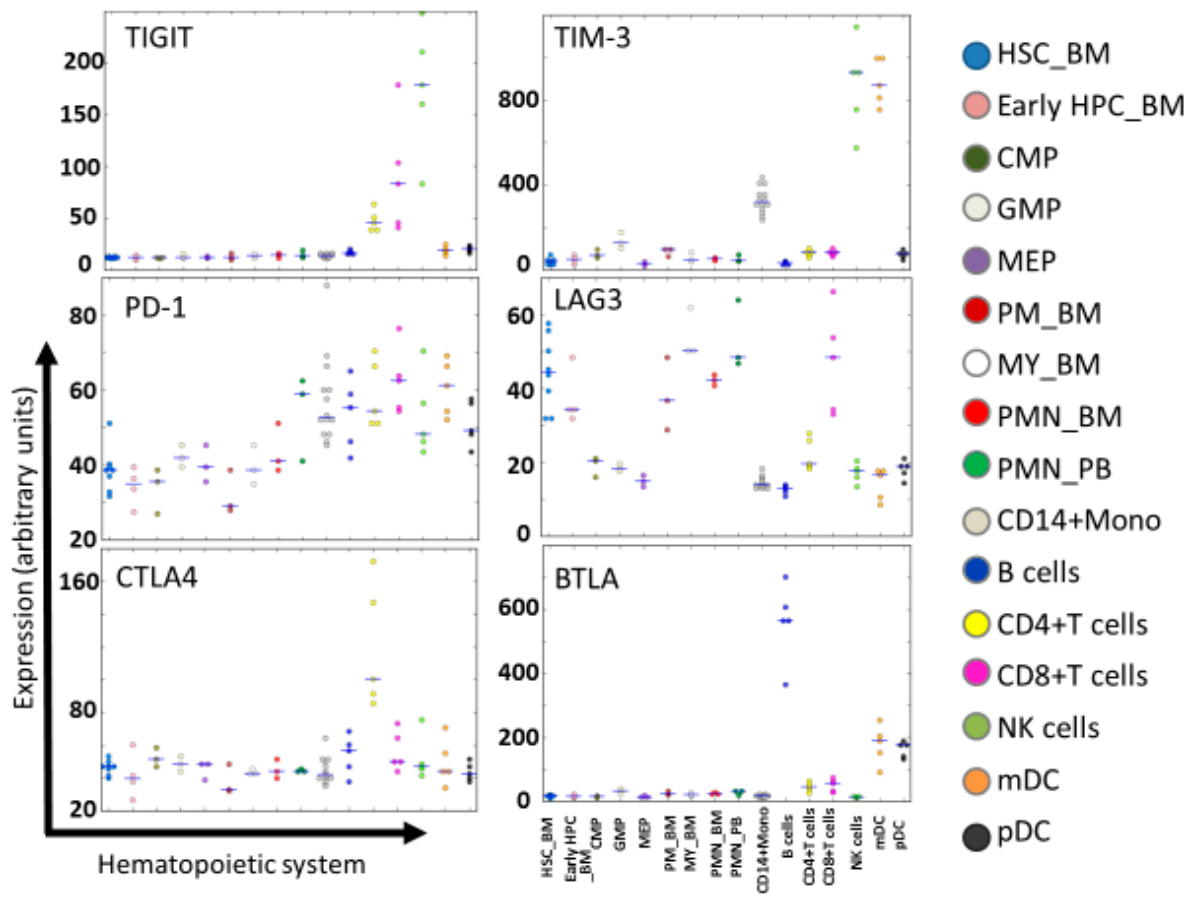

Figure 5. Expression of immune checkpoint receptors in normal hematopoiesis. Expression levels of TIGIT, TIM-3, PD-1, CTLA-4, LAG-3, and BTLA in the hematopoietic system at different maturation stages are shown according to HemaExplorer ${ }^{54,55}$, based on curated microarray data. Abbreviations: HSC_BM, hematopoietic stem cells from bone marrow; early HPC_BM, hematopoietic progenitor cells from bone marrow; CMP, common myeloid progenitor cell; GMP, granulocyte monocyte progenitors; MEP, megakaryocyte-erythroid progenitor cell; PM_BM, promyelocyte from bone marrow; MY_BM, myelocyte from bone marrow; PMN_BM, polymorphonuclear cells from bone marrow; PMN_PB, polymorphonuclear cells from peripheral blood; B-cells, CD19 ${ }^{+}$B-cells; NK cells; $\mathrm{CD}_{5} 6^{+}$natural killer cells; $\mathrm{mDC}, \mathrm{CD} 11 \mathrm{c}^{+}$myeloid dendritic cells; $\mathrm{pDC}, \mathrm{CD} 123^{+}$plasmacytoid dendritic cells. 
NK cells express various immune checkpoint receptors such as KIR-2D, NKG2A, PD-1, CTLA-4, TIGIT, TIM-3, LAG-3, and BTLA, which can interact with their cognate ligands on tumor cells or on several immune cells. Immune checkpoint inhibitors can interrupt their receptor's inhibitory signal.

IPH2101, also known as anti-KIR1-7F9 monoclonal antibody (mAb; lirilumab is a recombinant version of this mAb), blocks common inhibitory KIRs (KIR2DL/DS-1, -2, and -3), which bind to HLA-C alleles and augment NK cell-mediated killing in HLA-C-expressing leukemia cells [60]. Although this KIR2D blockade showed no clinical effectiveness [61] in a phase 2 trial in smoldering multiple myeloma (NCT01248455), adoptive transfer of NK cells combined with IPH2101 after allo-HSCT may have a therapeutic benefit. With lirilumab as with ICIs, CD94-NKG2A receptors on NK cells primarily recognize HLA-E, which is expressed by leukemia cells. Anti-NKG2A mAb (monalizumab) administration showed anti-leukemia effects in hematologic malignancies [62-64]. Previous studies have demonstrated that anti-NKG2A mAb can induce NKG2A ${ }^{+}$NK cell killing activity against HLA-E-expressing leukemia cells in vitro and in vivo [62-64]. Additionally, reduced numbers of NKG2A ${ }^{+}$NK cells after allo-HSCT are associated with the occurrence of severe GVHD $[65,66]$. Moreover, $\mathrm{NKG}_{2} \mathrm{~A}^{+} \mathrm{NK}$ cells inhibited T-cell proliferation and activation and might prevent GVHD [66]. Therefore, NKG2A ${ }^{+}$NK cells may play a crucial role in GVHD and GVL effect following allo-HSCT, and monalizumab administration may have a promising clinical role following allo-HSCT.

TIGIT is expressed by both T and NK cells, and its ligands are the poliovirus receptors PVR (also known as CD155) and PVRL2 (also known as CD112) [30]. PVR is overexpressed in several tumors including AML, and its overexpression has been linked to a poor prognosis in AML $[35,67,68]$. Meanwhile, AML patients with higher TIGIT expression after allo-HSCT had an inferior prognosis [35]. Previous studies have shown that blockade of TIGIT could prevent the exhaustion of NK cells and enhance NK cell-dependent antitumor effect [20,69]. Additionally, CMV-induced adaptive NK cells had less TIGIT expression compared to conventional NK cells, and overcame myeloid-derived suppressor cell (MDSC)-mediated immune suppression. The cytotoxic function of NK cells co-cultured with MDSCs against tumor cells could be restored by blockade of TIGIT [70]. Unlike PD-1 and CTLA-4 inhibitors, NK cells may play a critical role in TIGIT-based immunotherapy, and blockade of TIGIT may have therapeutic effects in GVL by controlling NK-cell activity after allo-HSCT. However, because blockade of TIGIT can also promote T-cell activity [71], it is imperative to optimize the clinical setting to prevent severe GVHD and intensify the GVL effect in AML patients undergoing allo-HSCT.

TIM-3 is expressed on all mature $\mathrm{CD} 56^{\mathrm{dim}} \mathrm{CD} 16^{+}$NK cells and activated immature CD56 ${ }^{\text {bright }} \mathrm{CD} 16^{-}$NK cells. Its ligand is galectin-9 [72], which induces interferon-gamma (IFN- $\gamma$ ) production by NK cells [73]. TIM-3 blockade restores NK cell exhaustion and leads to an increased NK cell cytotoxicity in several cancers [74,75], whereas the TIM-3 antibody agonist leads to a decrease in the cytotoxicity of NK cells [72]. TIM-3 blockade reduces NK cell-mediated killing of pancreatic cancer cell lines [76]. Although a phase 1 study evaluating the blockade of TIM-3 (TSR-022) in advanced solid tumors is in progress (NCT02817633), further studies will be needed to determine the precise role of TIM-3 in AML after allo-HSCT.

LAG-3 (also known as CD223) is a ligand which has been identified as MHC class II. It is widely expressed not only on activated T and NK cells but also on dendritic and B-cells (Figure 5) [75,77,78]. LAG-3 is involved in inhibiting T-cell effector function, and blockade of LAG-3 promotes T-cell proliferation in vitro [79]. However, the function of LAG-3 on NK cells remains unclear. Blockade of LAG-3 had no effect on NK-cell-mediated cytotoxicity [80]. Further investigation on the role of LAG-3 on NK cells is necessary.

BTLA (also known as CD272), which belongs to the immunoglobulin superfamily, is expressed by most lymphocytes (Figure 5). BTLA acts as a negative modulator of immune responses regulating T-cell activation and proliferation $[77,81,82]$. Its ligand, herpesvirus entry mediator (HVEM, also known as TNFSF14), is expressed in several tumor cells [82,83]. Blocking BTLA-HVEM interaction leads to a decrease in suppressor T-cells in the tumor microenvironment and enhances antitumor immunity [84]. Additionally, BTLA blockade promotes an increase in NKT-cells and expression of 
cytotoxic marker genes [85]. However, the functional role of BTLA on NK cells is controversial and requires further investigation.

\section{Bi/Trispecific Engagers and Chimeric Antigen Receptors (CAR) NK Cells}

Bispecific and trispecific killer cell engagers (BiKEs and TriKEs), which are composed of a single-chain variable fragment ( $\mathrm{scFv}$ ) containing a variable heavy and variable light chain of an antibody, can specifically target both CD16 expressed on NK cells and tumor antigens (Figure 2). Previous studies have shown that NK-cell-mediated cytotoxicity could occur by CD16 $\times$ CD33 (1633) BiKEs that ligated CD16 on NK cells and CD33 on tumor cells, including myelodysplastic syndromes (MDS) and AML [86,87]. Recently, 161533 TriKE, which is an NK-cell stimulatory cytokine with IL-15 added onto BiKE, has been found to restore NK cell proliferation and function through a low expression of TIGIT in NK cells. It is also able to enhance NK-cell-mediated cytotoxicity against MDS cells more than 1633 BiKE [88]. Moreover, NK cells treated with 161533 TriKE can overcome immune suppression mediated by MDSCs. Although IL-15 also stimulates cytotoxic T-cells, 161533 TriKE induces the proliferation of NK cells with minimal effect on T-cells [87]. Therefore, the administration of this agent after allo-HSCT may be a potentially promising treatment to decrease relapse of AML after allo-HSCT with less T-cell-mediated GVHD.

Chimeric antigen receptors (CARs) consist of scFv (extracellular domains) combined with $\mathrm{CD} 3 \zeta$, DAP10, or DAP12 as intracellular signal domains, and CD28, 4-1BB (also known as CD137), and 2B4 (also known as CD244) as costimulatory domains (Figure 2) [89-93]. In a murine allogeneic transplant model using donor-derived CD19-CAR T-cells, allogeneic CAR T-cells eliminated acute lymphoblastic leukemia [94]. However, its administration caused lethal GVHD. Additionally, CD123-redirected T-cells (CART123) eliminated AML and also eradicated normal hematopoietic stem cells (HSCs) in a mouse model because CD123 is highly expressed in HSC [95]. In a phase 1 clinical trial of CD33-CAR NK cells for relapsed and refractory AML patients (NCT02944162), the administration of CD33-CAR NK cells was not clinically efficacious [92]. Recently, cord blood-derived NK cells with CAR-CD19, IL-15, and inducible caspase-9-based suicide gene (iC9) (iC9/CAR.19/IL15-transduced CB-NK cells) enhanced their cytotoxicity against CD19-expressing tumors in a murine model [96]. CAR NK cells may provide a cost-effective treatment with a reduced risk of GVHD compared to CAR T-cells, but further clinical studies will be needed to demonstrate the safety and efficacy of CAR NK cells against AML following allo-HSCT.

\section{AML Survival Mechanism against NK Cells}

NK cell-based immunotherapies may emerge as a promising option for elimination of AML following allo-HSCT, but several factors may limit NK cell-based immunotherapies (Figure 3) [97-99]. For instance, the tumor microenvironment, which includes Tregs, tumor-associated macrophages, and MDSCs, which interfere with the function of NK cells, is a major limitation to the effectiveness of NK cells $[70,87,100,101]$. In addition, the tumor microenvironment possesses increased anti-inflammatory cytokines, such as TGF- $\beta$, IL-4, and IL-10, which cause immune evasion and result in decreased pro-inflammatory cytokines, including IFN- $\gamma$ and IL-15, which stimulate NK cell activation $[51,99,102]$. Moreover, leukemia cells produce several enzymes such as indoleamine 2,3-dioxygenase-1, arginase, prostaglandin-E2, CD39, and CD73, which reduce NK-cell proliferation and/or activity [98-100,103-106].

The incidence of HLA loss following allo-HCT is one of the major immune escape mechanisms that lead to relapse in AML, and may account for approximately one third of all relapses [107]. Because loss of mismatched HLA through copy-neutral loss of heterozygosity results in the elimination of the incompatible HLA alleles while keeping the expression of HLA class I molecules, cytotoxic killing by NK cells does not occur. Also, recent studies have shown that the downregulation of HLA class II molecules (HLA-DPA1, HLA-DPB1, HLA-DQB1, and HLA-DRB1) and their related molecules (CIITA, IFI30, HLA-DMA, HLA-DMB, and CD74) could allow leukemia relapse after allo-HSCT [108]. 
Patients who exhibited a high expression of CD200, CD47, PD-L1, PVR, or PVRL2, which is associated with an immune response or immune checkpoints, had a poor prognosis [35,67,109-111]. In addition to PD-1, exhausted T-cells, including exhausted CD8 ${ }^{+}$T-cells, express inhibitory receptors such as CTLA-4, LAG-3, and TIM-3 [21,112,113]. T-cell exhaustion contributes to AML relapse after allo-HSCT [113]. In contrast to T-cell exhaustion, expression of activating NKG2D ligands such as MHC class I-related chain A (MICA) and UL16-binding protein 1 (ULBP1) on AML cells at diagnosis is associated with an improved OS and a reduced incidence of relapse [114]. Activated NKG2D on NK cells recognizes NKG2D ligands (MICA/B and ULBPs) and enables the induction of NK-cell-mediated cytotoxicity on AML cells $[115,116]$. AML cells which express low levels of NKG2D ligands are able to evade immune surveillance by NK cells [115].

Janus kinase (JAK) mutations affect the interferon (IFN) signaling pathway by inducing an increase in STAT1 expression, the loss of beta-2-microglobulin, which can detect HLA class I antigen processing, and the loss of PTEN, which increases the production of immunosuppressive cytokines such as VEGF and can increase STAT3 expression. These mutations, which represent various mechanisms of resistance to ICIs, have been reported in several cancers [117-120], but it remains unknown in the case of AML. These studies demonstrated the association between T-cell activity and resistance to ICIs. However, the mechanisms of resistance to ICIs on NK cells are less well explored and require further elucidation.

\section{Conclusions}

Currently, there are numerous NK cell-based immunotherapies for AML post allo-HSCT that have been incorporated into pre-clinical and clinical trials. We have described some clinical trials associated with NK cell-based immunotherapies (Table 1). NK cell immunotherapies such as adoptive NK cells, cytokine-based therapies, ICIs, and bi/trispecific engagers have the potential to significantly enhance conventional therapies for the elimination of AML after allo-HSCT. In the future, combinations of these approaches require to be optimized to further enforce donor NK-cell mediated GVL in AML patients who received allo-HSCT. Moreover, for the next generation of NK-cell immunotherapies, therapeutic approaches based on CAR-engineered NK cells, memory-like NK cells, NKT-cells, and induced pluripotent stem cell-derived NK cells may be considered in a future study [49,89,121-124]. However, particularly with the use of ICIs, especially PD-1 or CTLA-4 blockade, after allo-HSCT, there is a distinct need for caution due to the risk of GVHD-related mortality. These ICIs appear to promote T-cell activity more than NK-cell activity against leukemia cells. Well-designed clinical trials should be required to demonstrate the safety and efficacy of these therapies. In addition, because NK cells have a short lifespan compared to T-cells, further improvements in manufacturing and expansion techniques are needed. Previously, immunotherapies had primarily focused on T-cell-mediated cytotoxicity. Thus, some mechanisms for NK-cell immunotherapies, including immune escape of AML, remain unclear. Further studies will be needed to predict which type of AML after allo-HSCT will be affected by NK-cell immunotherapies. The collection of large patient series and datasets will allow the investigation of the various factors which may potentially influence NK-cell immune responses. These factors will include the expression genes, mutations, alterations of resistance to immunotherapies in leukemia cells, tumor microenvironment consisting of Tregs, tumor-associated macrophages, MDSCs, and the production of cytokines.

Table 1. Selected list of clinical trials in NK cell-based immunotherapies.

\begin{tabular}{|c|c|c|c|c|c|}
\hline \multicolumn{6}{|c|}{ Adoptive NK Cells } \\
\hline Clinical Trial & Cytokines & Disease & Phase & Status & allo-HSCT \\
\hline NCT02229266 & IL-2 & AML & II & Recruiting & \\
\hline NCT00394381 & IL-2 & AML, MDS & $\mathrm{I} / \mathrm{II}$ & Completed & yes \\
\hline NCT01370213 & IL-2 & AML, MDS & II & Unknown & yes \\
\hline NCT01947322 & IL-2 & AML & $\mathrm{I} / \mathrm{II}$ & Completed & yes \\
\hline NCT03068819 & IL12, IL15, IL18 & AML & I & Recruiting & yes \\
\hline NCT02782546 & ALT-803 (IL-15) & AML & II & Recruiting & yes \\
\hline NCT02890758 & ALT-803 (IL-15) & HMs, solid tumors & I & Recruiting & \\
\hline NCT00460694 & IL-2 & HMs & $\mathrm{I} / \mathrm{II}$ & Completed & yes \\
\hline
\end{tabular}


Table 1. Cont.

\begin{tabular}{|c|c|c|c|c|c|}
\hline $\begin{array}{l}\text { NCT01823198 } \\
\text { NCT02809092 } \\
\text { NCT03300492 }\end{array}$ & $\begin{array}{c}\text { IL-2 } \\
\text { IL-21 } \\
-\end{array}$ & $\begin{array}{c}\text { HMs } \\
\text { AML } \\
\text { AML, MDS }\end{array}$ & $\begin{array}{l}\mathrm{I} / \mathrm{II} \\
\mathrm{I} / \mathrm{II} \\
\mathrm{I} / \mathrm{II}\end{array}$ & $\begin{array}{l}\text { Recruiting } \\
\text { Recruiting } \\
\text { Recruiting }\end{array}$ & $\begin{array}{l}\text { yes } \\
\text { yes }\end{array}$ \\
\hline \multicolumn{6}{|c|}{ Immune Checkpoint Inhibitors } \\
\hline Clinical Trial & Target & Disease & Phase & Status & allo-HSCT \\
\hline $\begin{array}{l}\text { IPH2101 } \\
\quad \text { NCT01256073 }\end{array}$ & KIR & AML & I & Completed & \\
\hline $\begin{array}{l}\text { IPH2102 } \\
\text { NCT01687387 } \\
\text { Lirilumab }\end{array}$ & KIR & AML & II & Completed & \\
\hline $\begin{array}{l}\text { NCT01687387 } \\
\text { NCT02399917 }\end{array}$ & $\begin{array}{l}\text { KIR2D } \\
\text { KIR2D }\end{array}$ & $\begin{array}{l}\text { AML } \\
\text { AML }\end{array}$ & $\begin{array}{l}\text { II } \\
\text { II }\end{array}$ & $\begin{array}{l}\text { Completed } \\
\text { Completed }\end{array}$ & \\
\hline $\begin{array}{l}\text { Monalizumab } \\
\text { NCT02921685 } \\
\text { Nivolumab }\end{array}$ & NKG2A & HMs & I & Recruiting & yes \\
\hline NCT03600155 & $\begin{array}{l}\text { PD- } 1 \text { and } \\
\text { CTLA-4 }\end{array}$ & AML & I & Recruiting & yes \\
\hline NCT02846376 & $\begin{array}{l}\text { PD-1 and/or } \\
\text { CTLA-4 }\end{array}$ & AML, MDS & I & Recruiting & yes \\
\hline $\begin{array}{l}\text { NCT01822509 } \\
\text { Pembrolizumab }\end{array}$ & PD-1 or CTLA-4 & HMs & I & Active, not recruiting & yes \\
\hline $\begin{array}{l}\text { NCT02981914 } \\
\text { Atezolizumab }\end{array}$ & PD-1 & AML, MDS, ML & I & Recruiting & yes \\
\hline $\begin{array}{l}\text { NCT02862275 } \\
\text { Avelumab }\end{array}$ & PD-L1 & HMs, solid tumors & I & Recruiting & \\
\hline $\begin{array}{c}\text { NCT02953561 } \\
\text { Durvalumab }\end{array}$ & PD-L1 & AML & $\mathrm{I} / \mathrm{II}$ & Recruiting & \\
\hline $\begin{array}{l}\text { NCT02775903 } \\
\text { Ipilimumab }\end{array}$ & PD-L1 & AML, MDS & II & Active, not recruiting & \\
\hline NCT03912064 & CTLA-4 & AML, MDS & I & Not yet recruiting & yes \\
\hline $\begin{array}{l}\text { NCT00060372 } \\
\text { OMP-313M32 }\end{array}$ & CTLA-4 & AML, solid tumors & I & Completed & yes \\
\hline $\begin{array}{l}\text { NCT03119428 } \\
\text { MTIG7192A }\end{array}$ & TIGIT & solid tumors & I & Active, not recruiting & \\
\hline $\begin{array}{l}\text { NCT03563716 } \\
\text { AB154 }\end{array}$ & TIGIT and PD-L1 & solid tumors & II & Active, not recruiting & \\
\hline $\begin{array}{l}\text { NCT03628677 } \\
\text { TSR-022 }\end{array}$ & TIGIT & solid tumors & I & Recruiting & \\
\hline $\begin{array}{l}\text { NCT02817633 } \\
\text { NCT02817633 }\end{array}$ & $\begin{array}{l}\text { TIM-3 and PD-1 } \\
\text { TIM-3 }\end{array}$ & $\begin{array}{l}\text { solid tumors } \\
\text { solid tumors }\end{array}$ & $\begin{array}{l}\text { II } \\
\text { I }\end{array}$ & $\begin{array}{l}\text { Not yet recruiting } \\
\text { Recruiting }\end{array}$ & \\
\hline MBG453 & & & & & \\
\hline $\begin{array}{c}\text { NCT03066648 } \\
\text { BMS-986016/BMS }\end{array}$ & $36558{ }^{\text {TIM-3 }}$ & AML, MDS & I & Recruiting & \\
\hline $\begin{array}{l}\text { NCT02061761 } \\
\text { Sym022 }\end{array}$ & LAG-3 & ML & $\mathrm{I} / \mathrm{II}$ & Recruiting & \\
\hline NCT03489369 & LAG-3 & ML, solid tumors & I & Recruiting & \\
\hline
\end{tabular}

\begin{tabular}{|c|c|c|c|c|c|}
\hline \multicolumn{6}{|l|}{$\begin{array}{l}\text { NK Cell } \\
\text { Engagers }\end{array}$} \\
\hline Clinical Trial & Target & Disease & Phase & Status & \\
\hline \multicolumn{6}{|l|}{ TriKEs } \\
\hline NCT03214666 & CD16/IL-15/CD33 & AML, MDS & $\mathrm{I} / \mathrm{II}$ & Not yet recruiting & \\
\hline \multicolumn{6}{|l|}{ CAR-NK Cells } \\
\hline Clinical Trial & Target & Disease & Phase & Status & Origin of NK Cells \\
\hline NCT02742727 & CD7 & AML, ALL, ML & $\mathrm{I} / \mathrm{II}$ & Unknown & NK-92 \\
\hline NCT02944162 & CD33 & AML & $\mathrm{I} / \mathrm{II}$ & Unknown & NK-92 \\
\hline NCT03579927 & CD19 & ML & $\mathrm{I} / \mathrm{II}$ & Not yet recruiting & UCB \\
\hline NCT03056339 & CD19 & ALL, ML & $\mathrm{I} / \mathrm{II}$ & Recruiting & UCB \\
\hline NCT02892695 & CD19 & ALL, ML & I/II & Recruiting & NK-92 \\
\hline NCT01974479 & CD19 & ALL & I & Suspended & Haploidentical donor NK cells \\
\hline NCT00995137 & CD19 & ALL & I & Completed & Expanded donor NK cells \\
\hline
\end{tabular}

Abbreviations: allo-HSCT, allogeneic hematopoietic stem cell transplantation; AML, acute myeloid leukemia; MDS, myelodysplastic syndromes; HMs, hematological malignancies; ML, malignant lymphoma; ALL, acute lymphoblastic leukemia. 
Conflicts of Interest: The authors declare no conflicts of interest.

\section{Abbreviations}

allo-HSCT allogeneic hematopoietic stem cell transplantation

AML acute myeloid leukemia

GVL graft-versus-leukemia

NK Natural killer

MRD minimal residual disease

DLI Donor lymphocyte infusion

ICIs immune checkpoint inhibitors

HLA human leukocyte antigen

TIGIT T-cell immunoreceptor with Ig and immunoreceptor tyrosine-based inhibition motif domains

GVHD graft versus host disease

OS overall survival

Tregs T-regulatory cells

CR complete remission

KIRs killer immunoglobulin-like receptors

PD-1 programmed cell death protein 1

CTLA-4 cytotoxic T-lymphocyte-associated protein 4

TIM-3 T-cell immunoglobulin and mucin domain-containing protein 3

LAG-3 lymphocyte activation gene 3

BTLA B- and T-lymphocyte attenuator

MDSC myeloid-derived suppressor cell

HVEM herpesvirus entry mediator

BiKEs bispecific killer cell engagers

TriKEs trispecific killer cell engagers

MDS myelodysplastic syndromes

CARs chimeric antigen receptors

HSCs hematopoietic stem cells

MICA MHC class I-related chain A

ULBP1 UL16-binding protein 1

HSC_BM hematopoietic stem cells from bone marrow

early

HPC_BM

CMP

GMP

MEP

PM_BM

MY_BM

hematopoietic progenitor cells from bone marrow

PMN_BM polymorphonuclear cells from bone marrow

PMN_PB polymorphonuclear cells from peripheral blood

B-cells $\quad \mathrm{CD} 19^{+} \mathrm{B}$-cells

NK cells $\quad \mathrm{CD}^{+} 6^{+}$natural killer cells

mDC $\quad$ CD11 $\mathrm{c}^{+}$myeloid dendritic cells

pDC $\quad \mathrm{CD}_{2} 3^{+}$plasmacytoid dendritic cells

HMs hematological malignancies

ML malignant lymphoma

ALL acute lymphoblastic leukemia

JAK Janus kinase

IFN interferon 


\section{References}

1. Schmid, C.; Labopin, M.; Nagler, A.; Niederwieser, D.; Castagna, L.; Tabrizi, R.; Stadler, M.; Kuball, J.; Cornelissen, J.; Vorlicek, J.; et al. Treatment, risk factors, and outcome of adults with relapsed AML after reduced intensity conditioning for allogeneic stem cell transplantation. Blood 2012, 119, 1599-1606. [CrossRef] [PubMed]

2. Bejanyan, N.; Weisdorf, D.J.; Logan, B.R.; Wang, H.L.; Devine, S.M.; de Lima, M.; Bunjes, D.W.; Zhang, M.J. Survival of patients with acute myeloid leukemia relapsing after allogeneic hematopoietic cell transplantation: A center for international blood and marrow transplant research study. Biol. Blood Marrow Transplant. 2015, 21, 454-459. [CrossRef] [PubMed]

3. Schroeder, T.; Rachlis, E.; Bug, G.; Stelljes, M.; Klein, S.; Steckel, N.K.; Wolf, D.; Ringhoffer, M.; Czibere, A.; Nachtkamp, K.; et al. Treatment of acute myeloid leukemia or myelodysplastic syndrome relapse after allogeneic stem cell transplantation with azacitidine and donor lymphocyte infusions-A retrospective multicenter analysis from the German Cooperative Transplant Study Group. Biol. Blood Marrow Transplant. 2015, 21, 653-660. [CrossRef] [PubMed]

4. Vyas, P.; Appelbaum, F.R.; Craddock, C. Allogeneic hematopoietic cell transplantation for acute myeloid leukemia. Biol. Blood Marrow Transplant. 2015, 21, 8-15. [CrossRef] [PubMed]

5. Tsirigotis, P.; Byrne, M.; Schmid, C.; Baron, F.; Ciceri, F.; Esteve, J.; Gorin, N.C.; Giebel, S.; Mohty, M.; Savani, B.N.; et al. Relapse of AML after hematopoietic stem cell transplantation: Methods of monitoring and preventive strategies. A review from the ALWP of the EBMT. Bone Marrow Transplant. 2016, 51, 1431-1438. [CrossRef]

6. Kassim, A.A.; Savani, B.N. Hematopoietic stem cell transplantation for acute myeloid leukemia: A review. Hematol. Oncol. Stem Cell Ther. 2017, 10, 245-251. [CrossRef]

7. Getta, B.M.; Devlin, S.M.; Levine, R.L.; Arcila, M.E.; Mohanty, A.S.; Zehir, A.; Tallman, M.S.; Giralt, S.A.; Roshal, M. Multicolor flow cytometry and multigene next-generation sequencing are complementary and highly predictive for relapse in acute myeloid leukemia after allogeneic transplantation. Biol. Blood Marrow Transplant. 2017, 23, 1064-1071. [CrossRef]

8. Leung, W.; Pui, C.H.; Coustan-Smith, E.; Yang, J.; Pei, D.; Gan, K.; Srinivasan, A.; Hartford, C.; Triplett, B.M.; Dallas, M.; et al. Detectable minimal residual disease before hematopoietic cell transplantation is prognostic but does not preclude cure for children with very-high-risk leukemia. Blood 2012, 120, 468-472. [CrossRef]

9. Walter, R.B.; Gooley, T.A.; Wood, B.L.; Milano, F.; Fang, M.; Sorror, M.L.; Estey, E.H.; Salter, A.I.; Lansverk, E.; Chien, J.W.; et al. Impact of pretransplantation minimal residual disease, as detected by multiparametric flow cytometry, on outcome of myeloablative hematopoietic cell transplantation for acute myeloid leukemia. J. Clin. Oncol. 2011, 29, 1190-1197. [CrossRef]

10. Thanarajasingam, G.; Kim, H.T.; Cutler, C.; Ho, V.T.; Koreth, J.; Alyea, E.P.; Antin, J.H.; Soiffer, R.J.; Armand, P. Outcome and prognostic factors for patients who relapse after allogeneic hematopoietic stem cell transplantation. Biol. Blood Marrow Transplant. 2013, 19, 1713-1718. [CrossRef]

11. Orti, G.; Barba, P.; Fox, L.; Salamero, O.; Bosch, F.; Valcarcel, D. Donor lymphocyte infusions in AML and MDS: Enhancing the graft-versus-leukemia effect. Exp. Hematol. 2017, 48, 1-11. [CrossRef]

12. Jedlickova, Z.; Schmid, C.; Koenecke, C.; Hertenstein, B.; Baurmann, H.; Schwerdtfeger, R.; Tischer, J.; Kolb, H.J.; Schleuning, M. Long-term results of adjuvant donor lymphocyte transfusion in AML after allogeneic stem cell transplantation. Bone Marrow Transplant. 2016, 51, 663-667. [CrossRef]

13. Bacchetta, R.; Lucarelli, B.; Sartirana, C.; Gregori, S.; Lupo Stanghellini, M.T.; Miqueu, P.; Tomiuk, S.; Hernandez-Fuentes, M.; Gianolini, M.E.; Greco, R.; et al. Immunological outcome in haploidentical-HSC Transplanted Patients treated with IL-10-anergized donor T-cells. Front. Immunol. 2014, 5, 16. [CrossRef]

14. Platzbecker, U.; Wermke, M.; Radke, J.; Oelschlaegel, U.; Seltmann, F.; Kiani, A.; Klut, I.M.; Knoth, H.; Röllig, C.; Schetelig, J.; et al. Azacitidine for treatment of imminent relapse in MDS or AML patients after allogeneic HSCT: Results of the RELAZA trial. Leukemia 2012, 26, 381-389. [CrossRef]

15. Craddock, C.; Jilani, N.; Siddique, S.; Yap, C.; Khan, J.; Nagra, S.; Ward, J.; Ferguson, P.; Hazlewood, P.; Buka, R.; et al. Tolerability and clinical activity of post-transplantation azacitidine in patients allografted for acute myeloid leukemia treated on the RICAZA Trial. Biol. Blood Marrow Transplant. 2016, 22, 385-390. [CrossRef] 
16. Platzbecker, U.; Middeke, J.M.; Sockel, K.; Herbst, R.; Wolf, D.; Baldus, C.D.; Oelschlägel, U.; Mütherig, A.; Fransecky, L.; Noppeney, R.; et al. Measurable residual disease-guided treatment with azacitidine to prevent haematological relapse in patients with myelodysplastic syndrome and acute myeloid leukaemia (RELAZA2): An open-label, multicentre, phase 2 trial. Lancet Oncol. 2018, 19, 1668-1679. [CrossRef]

17. Armand, P. Immune checkpoint blockade in hematologic malignancies. Blood 2015, 125, 3393-3400. [CrossRef]

18. Dietz, A.C.; Wayne, A.S. Cells to prevent/treat relapse following allogeneic stem cell transplantation. Hematol. Am. Soc. Hematol. Educ. Program 2017, 2017, 708-715. [CrossRef]

19. Przespolewski, A.; Szeles, A.; Wang, E.S. Advances in immunotherapy for acute myeloid leukemia. Future Oncol. 2018, 14, 963-978. [CrossRef]

20. Cooley, S.; Parham, P.; Miller, J.S. Strategies to activate NK cells to prevent relapse and induce remission following hematopoietic stem cell transplantation. Blood 2018, 131, 1053-1062. [CrossRef]

21. Wong, E.; Davis, J.E.; Grigg, A.; Szer, J.; Ritchie, D. Strategies to enhance the graft versus tumour effect after allogeneic haematopoietic stem cell transplantation. Bone Marrow Transplant. 2018. [CrossRef]

22. Blazar, B.R.; MacDonald, K.P.A.; Hill, G.R. Immune regulatory cell infusion for graft-versus-host disease prevention and therapy. Blood 2018, 131, 2651-2660. [CrossRef]

23. Falkenburg, F.; Ruggiero, E.; Bonini, C.; Porter, D.; Miller, J.; Malard, F.; Mohty, M.; Kröger, N.; Kolb, H.J. Prevention and treatment of relapse after stem cell transplantation by cellular therapies. Bone Marrow Transplant. 2019, 54, 26-34. [CrossRef]

24. Hobo, W.; Hutten, T.J.A.; Schaap, N.P.M.; Dolstra, H. Immune checkpoint molecules in acute myeloid leukaemia: Managing the double-edged sword. Br. J. Haematol. 2018, 181, 38-53. [CrossRef]

25. Rotte, A.; Jin, J.Y.; Lemaire, V. Mechanistic overview of immune checkpoints to support the rational design of their combinations in cancer immunotherapy. Ann. Oncol. 2018, 29, 71-83. [CrossRef]

26. Li, X.; Shao, C.; Shi, Y.; Han, W. Lessons learned from the blockade of immune checkpoints in cancer immunotherapy. J. Hematol. Oncol. 2018, 11, 31. [CrossRef]

27. Jenkins, R.W.; Barbie, D.A.; Flaherty, K.T. Mechanisms of resistance to immune checkpoint inhibitors. Br. J. Cancer 2018, 118, 9-16. [CrossRef]

28. Gide, T.N.; Wilmott, J.S.; Scolyer, R.A.; Long, G.V. Primary and acquired resistance to immune checkpoint inhibitors in metastatic melanoma. Clin. Cancer Res. 2018, 24, 1260-1270. [CrossRef]

29. O'Donnell, J.S.; Teng, M.W.L.; Smyth, M.J. Cancer immunoediting and resistance to T-cell-based immunotherapy. Nat. Rev. Clin. Oncol. 2019, 16, 151-167. [CrossRef]

30. Leung, W. Use of NK cell activity in cure by transplant. Br. J. Haematol. 2011, 155, 14-29. [CrossRef]

31. He, Y.; Tian, Z. NK cell education via nonclassical MHC and non-MHC ligands. Cell. Mol. Immunol. 2017, 14, 321-330. [CrossRef]

32. Holtan, S.G.; Pasquini, M.; Weisdorf, D.J. Acute graft-versus-host disease: A bench-to-bedside update. Blood 2014, 124, 363-373. [CrossRef]

33. Shaffer, B.C.; Hsu, K.C. How important is NK alloreactivity and KIR in allogeneic transplantation? Best Pract. Res. Clin. Haematol. 2016, 29, 351-358. [CrossRef]

34. Hattori, N.; Saito, B.; Sasaki, Y.; Shimada, S.; Murai, S.; Abe, M.; Baba, Y.; Watanuki, M.; Fujiwara, S.; Kawaguchi, Y.; et al. Status of natural killer cell recovery in Day 21 bone marrow after allogeneic hematopoietic stem cell transplantation predicts clinical outcome. Biol. Blood Marrow Transplant. 2018, 24, 1841-1847. [CrossRef]

35. Hattori, N.; Kawaguchi, Y.; Sasaki, Y.; Shimada, S.; Murai, S.; Abe, M.; Baba, Y.; Watanuki, M.; Fujiwara, S.; Arai, N.; et al. Monitoring TIGIT/DNAM-1 and PVR/PVRL2 immune checkpoint expression levels in allogeneic stem cell transplantation for acute myeloid leukemia. Biol. Blood Marrow Transplant. 2019. [CrossRef]

36. Kim, S.Y.; Lee, H.; Han, M.S.; Shim, H.; Eom, H.S.; Park, B.; Kong, S.Y. Post-transplantation natural killer cell count: A predictor of acute graft-versus-host disease and survival outcomes after allogeneic hematopoietic stem cell transplantation. Clin. Lymphoma Myeloma Leuk. 2016, 16, 527-535. [CrossRef]

37. Minculescu, L.; Marquart, H.V.; Friis, L.S.; Petersen, S.L.; Schiødt, I.; Ryder, L.P.; Andersen, N.S.; Sengeloev, H. Early natural killer cell reconstitution predicts overall survival in T-cell-replete allogeneic hematopoietic stem cell transplantation. Biol. Blood Marrow Transplant. 2016, 22, 2187-2193. [CrossRef] 
38. Passweg, J.R.; Tichelli, A.; Meyer-Monard, S.; Heim, D.; Stern, M.; Kühne, T.; Favre, G.; Gratwohl, A. Purified donor NK-lymphocyte infusion to consolidate engraftment after haploidentical stem cell transplantation. Leukemia 2004, 18, 1835-1838. [CrossRef]

39. Yoon, S.R.; Lee, Y.S.; Yang, S.H.; Ahn, K.H.; Lee, J.H.; Lee, J.H.; Kim, D.Y.; Kang, Y.A.; Jeon, M.; Seol, M.; et al. Generation of donor natural killer cells from $\mathrm{CD}^{+} 4^{+}$progenitor cells and subsequent infusion after HLA-mismatched allogeneic hematopoietic cell transplantation: A feasibility study. Bone Marrow Transplant. 2010, 45, 1038-1046. [CrossRef]

40. Stern, M.; Passweg, J.R.; Meyer-Monard, S.; Esser, R.; Tonn, T.; Soerensen, J.; Paulussen, M.; Gratwohl, A.; Klingebiel, T.; Bader, P.; et al. Pre-emptive immunotherapy with purified natural killer cells after haploidentical SCT: A prospective phase II study in two centers. Bone Marrow Transplant. 2013, 48, 433-438. [CrossRef]

41. Choi, I.; Yoon, S.R.; Park, S.Y.; Kim, H.; Jung, S.J.; Jang, Y.J.; Kang, M.; Yeom, Y.I.; Lee, J.L.; Kim, D.Y.; et al. Donor-derived natural killer cells infused after human leukocyte antigen-haploidentical hematopoietic cell transplantation: A dose-escalation study. Biol. Blood Marrow Transplant. 2014, 20, 696-704. [CrossRef]

42. Choi, I.; Yoon, S.R.; Park, S.Y.; Kim, H.; Jung, S.J.; Kang, Y.L.; Lee, J.H.; Lee, J.H.; Kim, D.Y.; Lee, J.L.; et al. Donor-derived natural killer cell infusion after human leukocyte antigen-haploidentical hematopoietic cell transplantation in patients with refractory acute leukemia. Biol. Blood Marrow Transplant. 2016, 22, 2065-2076. [CrossRef]

43. Björklund, A.T.; Carlsten, M.; Sohlberg, E.; Liu, L.L.; Clancy, T.; Karimi, M.; Cooley, S.; Miller, J.S.; Klimkowska, M.; Schaffer, M.; et al. Complete remission with Reduction of High-Risk Clones following haploidentical NK-Cell Therapy against MDS and AML. Clin. Cancer Res. 2018, 24, 1834-1844. [CrossRef]

44. Dolstra, H.; Roeven, M.W.H.; Spanholtz, J.; Hangalapura, B.N.; Tordoir, M.; Maas, F.; Leenders, M.; Bohme, F.; Kok, N.; Trilsbeek, C.; et al. Successful transfer of umbilical cord blood CD34 ${ }^{+}$hematopoietic stem and progenitor-derived NK cells in older acute myeloid leukemia patients. Clin. Cancer Res. 2017, 23, 4107-4118. [CrossRef]

45. Miller, J.S.; Soignier, Y.; Panoskaltsis-Mortari, A.; McNearney, S.A.; Yun, G.H.; Fautsch, S.K.; McKenna, D.; Le, C.; Defor, T.E.; Burns, L.J.; et al. Successful adoptive transfer and in vivo expansion of human haploidentical NK cells in patients with cancer. Blood 2005, 105, 3051-3057. [CrossRef]

46. Rubnitz, J.E.; Inaba, H.; Ribeiro, R.C.; Pounds, S.; Rooney, B.; Bell, T.; Pui, C.H.; Leung, W. NKAML: A pilot study to determine the safety and feasibility of haploidentical natural killer cell transplantation in childhood acute myeloid leukemia. J. Clin. Oncol. 2010, 28, 955-959. [CrossRef]

47. Bachanova, V.; Cooley, S.; Defor, T.E.; Verneris, M.R.; Zhang, B.; McKenna, D.H.; Curtsinger, J.; Panoskaltsis-Mortari, A.; Lewis, D.; Hippen, K.; et al. Clearance of acute myeloid leukemia by haploidentical natural killer cells is improved using IL-2 diphtheria toxin fusion protein. Blood 2014, 123, 3855-3863. [CrossRef]

48. Curti, A.; Ruggeri, L.; Parisi, S.; Bontadini, A.; Dan, E.; Motta, M.R.; Rizzi, S.; Trabanelli, S.; Ocadlikova, D.; Lecciso, M.; et al. Larger size of donor alloreactive NK cell repertoire correlates with better response to NK cell immunotherapy in elderly acute myeloid leukemia patients. Clin. Cancer Res. 2016, 22, 1914-1921. [CrossRef]

49. Romee, R.; Rosario, M.; Berrien-Elliott, M.M.; Wagner, J.A.; Jewell, B.A.; Schappe, T.; Leong, J.W.; Abdel-Latif, S.; Schneider, S.E.; Willey, S.; et al. Cytokine-induced memory-like natural killer cells exhibit enhanced responses against myeloid leukemia. Sci. Transl. Med. 2016, 8, 357ra123. [CrossRef]

50. Song, Y.; Hu, B.; Liu, Y.; Jin, Z.; Zhang, Y.; Lin, D.; Zhu, Y.; Lei, L.; Gong, H.; Mei, Y.; et al. IL-12/IL-18-preactivated donor NK cells enhance GVL effects and mitigate GvHD after allogeneic hematopoietic stem cell transplantation. Eur. J. Immunol. 2018, 48, 670-682. [CrossRef]

51. Romee, R.; Cooley, S.; Berrien-Elliott, M.M.; Westervelt, P.; Verneris, M.R.; Wagner, J.E.; Weisdorf, D.J.; Blazar, B.R.; Ustun, C.; DeFor, T.E.; et al. First-in-human phase 1 clinical study of the IL-15 superagonist complex ALT-803 to treat relapse after transplantation. Blood 2018, 131, 2515-2527. [CrossRef]

52. Ciurea, S.O.; Schafer, J.R.; Bassett, R.; Denman, C.J.; Cao, K.; Willis, D.; Rondon, G.; Chen, J.; Soebbing, D.; Kaur, I.; et al. Phase 1 clinical trial using mbIL21 ex vivo-expanded donor-derived NK cells after haploidentical transplantation. Blood 2017, 130, 1857-1868. [CrossRef]

53. Olson, J.A.; Leveson-Gower, D.B.; Gill, S.; Baker, J.; Beilhack, A.; Negrin, R.S. NK cells mediate reduction of GVHD by inhibiting activated, alloreactive T-cells while retaining GVT effects. Blood 2010, 115, 4293-4301. [CrossRef] 
54. Bagger, F.O.; Rapin, N.; Theilgaard-Mönch, K.; Kaczkowski, B.; Thoren, L.A.; Jendholm, J.; Winther, O.; Porse, B.T. HemaExplorer: A database of mRNA expression profiles in normal and malignant haematopoiesis. Nucleic Acids Res. 2013, D1034-D1039. [CrossRef]

55. Bagger, F.O.; Rapin, N.; Theilgaard-Mönch, K.; Kaczkowski, B.; Jendholm, J.; Winther, O.; Porse, B. HemaExplorer: A Web server for easy and fast visualization of gene expression in normal and malignant hematopoiesis. Blood 2012, 119, 6394-6395. [CrossRef]

56. Bashey, A.; Medina, B.; Corringham, S.; Pasek, M.; Carrier, E.; Vrooman, L.; Lowy, I.; Solomon, S.R.; Morris, L.E.; Holland, H.K.; et al. CTLA4 blockade with ipilimumab to treat relapse of malignancy after allogeneic hematopoietic cell transplantation. Blood 2009, 113, 1581-1588. [CrossRef]

57. Zhou, J.; Bashey, A.; Zhong, R.; Corringham, S.; Messer, K.; Pu, M.; Ma, W.; Chut, T.; Soiffer, R.; Mitrovich, R.C.; et al. CTLA-4 blockade following relapse of malignancy after allogeneic stem cell transplantation is associated with T-cell activation but not with increased levels of T regulatory cells. Biol. Blood Marrow Transplant. 2011, 17, 682-692. [CrossRef]

58. Davids, M.S.; Kim, H.T.; Bachireddy, P.; Costello, C.; Liguori, R.; Savell, A.; Lukez, A.P.; Avigan, D.; Chen, Y.B.; McSweeney, P.; et al. Ipilimumab for patients with relapse after allogeneic transplantation. N. Engl. J. Med. 2016, 375, 143-153. [CrossRef]

59. Ijaz, A.; Khan, A.Y.; Malik, S.U.; Faridi, W.; Fraz, M.A.; Usman, M.; Tariq, M.J.; Durer, S.; Durer, C.; Russ, A.; et al. Significant risk of graft-versus-host disease with exposure to checkpoint inhibitors before and after allogeneic transplantation. Biol. Blood Marrow Transplant. 2019, 25, 94-99. [CrossRef]

60. Romagné, F.; André, P.; Spee, P.; Zahn, S.; Anfossi, N.; Gauthier, L.; Capanni, M.; Ruggeri, L.; Benson, D.M., Jr.; Blaser, B.W.; et al. Preclinical characterization of 1-7F9, a novel human anti-KIR receptor therapeutic antibody that augments natural killer-mediated killing of tumor cells. Blood 2009, 114, 2667-2677. [CrossRef]

61. Korde, N.; Carlsten, M.; Lee, M.J.; Minter, A.; Tan, E.; Kwok, M.; Manasanch, E.; Bhutani, M.; Tageja, N.; Roschewski, M.; et al. A phase II trial of pan-KIR2D blockade with IPH2101 in smoldering multiple myeloma. Haematologica 2014, 99, e81-e83. [CrossRef] [PubMed]

62. Nguyen, S.; Dhedin, N.; Vernant, J.P.; Kuentz, M.; Al Jijakli, A.; Rouas-Freiss, N.; Carosella, E.D.; Boudifa, A.; Debré, P.; Vieillard, V. NK-cell reconstitution after haploidentical hematopoietic stem-cell transplantations: Immaturity of NK cells and inhibitory effect of NKG2A override GvL effect. Blood 2005, 105, 4135-4142. [CrossRef] [PubMed]

63. Godal, R.; Bachanova, V.; Gleason, M.; McCullar, V.; Yun, G.H.; Cooley, S.; Verneris, M.R.; McGlave, P.B.; Miller, J.S. Natural killer cell killing of acute myelogenous leukemia and acute lymphoblastic leukemia blasts by killer cell immunoglobulin-like receptor-negative natural killer cells after NKG2A and LIR-1 blockade. Biol. Blood Marrow Transplant. 2010, 16, 612-621. [CrossRef] [PubMed]

64. Ruggeri, L.; Urbani, E.; André, P.; Mancusi, A.; Tosti, A.; Topini, F.; Bléry, M.; Animobono, L.; Romagné, F.; Wagtmann, N.; et al. Effects of anti-NKG2A antibody administration on leukemia and normal hematopoietic cells. Haematologica 2016, 101, 626-633. [CrossRef]

65. Kordelas, L.; Steckel, N.K.; Horn, P.A.; Beelen, D.W.; Rebmann, V. The activating NKG2C receptor is significantly reduced in NK cells after allogeneic stem cell transplantation in patients with severe graft-versus-host disease. Int. J. Mol. Sci. 2016, 17, 1797. [CrossRef]

66. Hu, L.J.; Zhao, X.Y.; Yu, X.X.; Lv, M.; Han, T.T.; Han, W.; Huang, X.J. Quantity and quality reconstitution of $\mathrm{NKG2A}$ + natural killer cells are associated with graft-versus-host disease after allogeneic hematopoietic cell transplantation. Biol. Blood Marrow Transplant. 2019, 25, 1-11. [CrossRef] [PubMed]

67. Stamm, H.; Klingler, F.; Grossjohann, E.M.; Muschhammer, J.; Vettorazzi, E.; Heuser, M.; Mock, U.; Thol, F.; Vohwinkel, G.; Latuske, E.; et al. Immune checkpoints PVR and PVRL2 are prognostic markers in AML and their blockade represents a new therapeutic option. Oncogene 2018, 37, 5269-5280. [CrossRef] [PubMed]

68. Gao, J.; Zheng, Q.; Xin, N.; Wang, W.; Zhao, C. CD155, an onco-immunologic molecule in human tumors. Cancer Sci. 2017, 108, 1934-1938. [CrossRef]

69. Zhang, Q.; Bi, J.; Zheng, X.; Chen, Y.; Wang, H.; Wu, W.; Wang, Z.; Wu, Q.; Peng, H.; Wei, H.; et al. Blockade of the checkpoint receptor TIGIT prevents NK cell exhaustion and elicits potent antitumor immunity. Nat. Immunol. 2018, 19, 723-732. [CrossRef] [PubMed]

70. Sarhan, D.; Cichocki, F.; Zhang, B.; Yingst, A.; Spellman, S.R.; Cooley, S.; Verneris, M.R.; Blazar, B.R.; Miller, J.S. Adaptive NK cells with low TIGIT expression are inherently resistant to myeloid-derived suppressor cells. Cancer Res. 2016, 76, 5696-5706. [CrossRef] 
71. Johnston, R.J.; Comps-Agrar, L.; Hackney, J.; Yu, X.; Huseni, M.; Yang, Y.; Park, S.; Javinal, V.; Chiu, H.; Irving, B.; et al. The immunoreceptor TIGIT regulates antitumor and antiviral CD8(+) T-cell effector function. Cancer Cell 2014, 26, 923-937. [CrossRef]

72. Ndhlovu, L.C.; Lopez-Vergès, S.; Barbour, J.D.; Jones, R.B.; Jha, A.R.; Long, B.R.; Schoeffler, E.C.; Fujita, T.; Nixon, D.F.; Lanier, L.L. Tim-3 marks human natural killer cell maturation and suppresses cell-mediated cytotoxicity. Blood 2012, 119, 3734-3743. [CrossRef]

73. Gleason, M.K.; Lenvik, T.R.; McCullar, V.; Felices, M.; O’Brien, M.S.; Cooley, S.A.; Verneris, M.R.; Cichocki, F.; Holman, C.J.; Panoskaltsis-Mortari, A.; et al. Tim-3 is an inducible human natural killer cell receptor that enhances interferon gamma production in response to galectin-9. Blood 2012, 119, 3064-3072. [CrossRef]

74. Gallois, A.; Silva, I.; Osman, I.; Bhardwaj, N. Reversal of natural killer cell exhaustion by TIM-3 blockade. Oncoimmunology 2014, 3, e946365. [CrossRef]

75. Kim, N.; Kim, H.S. Targeting checkpoint receptors and molecules for therapeutic modulation of natural killer cells. Front. Immunol. 2018, 9, 2041. [CrossRef]

76. Van Audenaerde, J.R.M.; De Waele, J.; Marcq, E.; Van Loenhout, J.; Lion, E.; Van den Bergh, J.M.J.; Jesenofsky, R.; Masamune, A.; Roeyen, G.; Pauwels, P.; et al. Interleukin-15 stimulates natural killer cell-mediated killing of both human pancreatic cancer and stellate cells. Oncotarget 2017, 8, 56968-56979. [CrossRef]

77. Torphy, R.J.; Schulick, R.D.; Zhu, Y. Newly emerging immune checkpoints: Promises for future cancer therapy. Int. J. Mol. Sci. 2017, 18, 2642. [CrossRef]

78. Beldi-Ferchiou, A.; Caillat-Zucman, S. Control of NK cell activation by immune checkpoint molecules. Int. J. Mol. Sci. 2017, 18, 2129. [CrossRef]

79. Maçon-Lemaître, L.; Triebel, F. The negative regulatory function of the lymphocyte-activation gene-3 co-receptor (CD223) on human T-cells. Immunology 2005, 115, 170-178. [CrossRef]

80. Huard, B.; Tournier, M.; Triebel, F. LAG-3 does not define a specific mode of natural killing in human. Immunol. Lett. 1998, 61, 109-112. [CrossRef]

81. Krieg, C.; Boyman, O.; Fu, Y.X.; Kaye, J. B and T lymphocyte attenuator regulates CD8 ${ }^{+}$T-cell-intrinsic homeostasis and memory cell generation. Nat. Immunol. 2007, 8, 162-171. [CrossRef] [PubMed]

82. Le Mercier, I.; Lines, J.L.; Noelle, R.J. Beyond CTLA-4 and PD-1, the generation Z of negative checkpoint regulators. Front. Immunol. 2015, 6, 418. [CrossRef] [PubMed]

83. Gertner-Dardenne, J.; Fauriat, C.; Orlanducci, F.; Thibult, M.L.; Pastor, S.; Fitzgibbon, J.; Bouabdallah, R.; Xerri, L.; Olive, D. The co-receptor BTLA negatively regulates human V $\gamma 9 \mathrm{~V} \delta 2 \mathrm{~T}$-cell proliferation: A potential way of immune escape for lymphoma cells. Blood 2013, 122, 922-931. [CrossRef] [PubMed]

84. Han, L.; Wang, W.; Fang, Y.; Feng, Z.; Liao, S.; Li, W.; Li, Y.; Li, C.; Maitituoheti, M.; Dong, H.; et al. Soluble B and T lymphocyte attenuator possesses antitumor effects and facilitates heat shock protein 70 vaccine-triggered antitumor immunity against a murine TC-1 cervical cancer model in vivo. J. Immunol. 2009, 183, 7842-7850. [CrossRef] [PubMed]

85. Sekar, D.; Govene, L.; Del Río, M.L.; Sirait-Fischer, E.; Fink, A.F.; Brüne, B.; Rodriguez-Barbosa, J.I.; Weigert, A. Downregulation of BTLA on NKT-cells promotes tumor immune control in a mouse model of mammary carcinoma. Int. J. Mol. Sci. 2018, 19, 752. [CrossRef] [PubMed]

86. Gleason, M.K.; Ross, J.A.; Warlick, E.D.; Lund, T.C.; Verneris, M.R.; Wiernik, A.; Spellman, S.; Haagenson, M.D.; Lenvik, A.J.; Litzow, M.R.; et al. CD16 × CD33 bispecific killer cell engager (BiKE) activates NK cells against primary MDS and MDSC CD33 ${ }^{+}$targets. Blood 2014, 123, 3016-3026. [CrossRef] [PubMed]

87. Vallera, D.A.; Felices, M.; McElmurry, R.; McCullar, V.; Zhou, X.; Schmohl, J.U.; Zhang, B.; Lenvik, A.J.; Panoskaltsis-Mortari, A.; Verneris, M.R.; et al. IL15 trispecific killer engagers (TriKE) make natural killer cells specific to $\mathrm{CD} 33^{+}$targets while Also Inducing Persistence, In Vivo Expansion, and Enhanced Function. Clin. Cancer Res. 2016, 22, 3440-3450. [CrossRef]

88. Sarhan, D.; Brandt, L.; Felices, M.; Guldevall, K.; Lenvik, T.; Hinderlie, P.; Curtsinger, J.; Warlick, E.; Spellman, S.R.; Blazar, B.R.; et al. 161533 TriKE stimulates NK-cell function to overcome myeloid-derived suppressor cells in MDS. Blood Adv. 2018, 2, 1459-1469. [CrossRef] [PubMed]

89. Hu, Y.; Tian, Z.G.; Zhang, C. Chimeric antigen receptor (CAR)-transduced natural killer cells in tumor immunotherapy. Acta Pharmacol. Sin. 2018, 39, 167-176. [CrossRef]

90. Oberschmidt, O.; Kloess, S.; Koehl, U. Redirected primary human chimeric antigen receptor natural killer cells as an 'off-the-shelf immunotherapy' for improvement in cancer treatment. Front. Immunol. 2017, 8, 654. [CrossRef] 
91. Demoulin, B.; Cook, W.J.; Murad, J.; Graber, D.J.; Sentman, M.L.; Lonez, C.; Gilham, D.E.; Sentman, C.L.; Agaugue, S. Exploiting natural killer group 2D receptors for CAR T-cell therapy. Future Oncol. 2017, 13, 1593-1605. [CrossRef]

92. Tang, X.; Yang, L.; Li, Z.; Nalin, A.P.; Dai, H.; Xu, T.; Yin, J.; You, F.; Zhu, M.; Shen, W.; et al. First-in-man clinical trial of CAR NK-92 cells: Safety test of CD33-CAR NK-92 cells in patients with relapsed and refractory acute myeloid leukemia. Am. J. Cancer Res. 2018, 8, 1083-1089.

93. Zhang, J.; Zheng, H.; Diao, Y. Natural killer cells and current applications of chimeric antigen receptor-modified NK-92 cells in tumor immunotherapy. Int. J. Mol. Sci. 2019, 20, 317. [CrossRef]

94. Jacoby, E.; Yang, Y.; Qin, H.; Chien, C.D.; Kochenderfer, J.N.; Fry, T.J. Murine allogeneic CD19 CAR T-cells harbor potent antileukemic activity but have the potential to mediate lethal GVHD. Blood 2016, 127, 1361-1370. [CrossRef]

95. Gill, S.; Tasian, S.K.; Ruella, M.; Shestova, O.; Li, Y.; Porter, D.L.; Carroll, M.; Danet-Desnoyers, G.; Scholler, J.; Grupp, S.A.; et al. Preclinical targeting of human acute myeloid leukemia and myeloablation using chimeric antigen receptor-modified T-cells. Blood 2014, 123, 2343-2354. [CrossRef]

96. Liu, E.; Tong, Y.; Dotti, G.; Shaim, H.; Savoldo, B.; Mukherjee, M.; Orange, J.; Wan, X.; Lu, X.; Reynolds, A.; et al. Cord blood NK cells engineered to express IL-15 and a CD19-targeted CAR show long-term persistence and potent antitumor activity. Leukemia 2018, 32, 520-531. [CrossRef]

97. Martín-Antonio, B.; Suñe, G.; Perez-Amill, L.; Castella, M.; Urbano-Ispizua, A. Natural killer cells: Angels and devils for immunotherapy. Int. J. Mol. Sci. 2017, 18, 1868. [CrossRef]

98. Daher, M.; Rezvani, K. Next generation natural killer cells for cancer immunotherapy: The promise of genetic engineering. Curr. Opin. Immunol. 2018, 51, 146-153. [CrossRef]

99. Zeiser, R.; Vago, L. Mechanisms of immune escape after allogeneic hematopoietic cell transplantation. Blood 2018. [CrossRef]

100. Murray, S.; Lundqvist, A. Targeting the tumor microenvironment to improve natural killer cell-based immunotherapies: On being in the right place at the right time, with resilience. Hum. Vaccin. Immunother. 2016, 12, 607-611. [CrossRef]

101. Sabry, M.; Lowdell, M.W. Tumor-primed NK cells: Waiting for the green light. Front. Immunol. 2013, 4, 408. [CrossRef] [PubMed]

102. DiLillo, D.J.; Weinberg, J.B.; Yoshizaki, A.; Horikawa, M.; Bryant, J.M.; Iwata, Y.; Matsushita, T.; Matta, K.M.; Chen, Y.; Venturi, G.M.; et al. Chronic lymphocytic leukemia and regulatory B-cells share IL-10 competence and immunosuppressive function. Leukemia 2013, 27, 170-182. [CrossRef]

103. Folgiero, V.; Goffredo, B.M.; Filippini, P.; Masetti, R.; Bonanno, G.; Caruso, R.; Bertaina, V.; Mastronuzzi, A.; Gaspari, S.; Zecca, M.; et al. Indoleamine 2,3-dioxygenase 1 (IDO1) activity in leukemia blasts correlates with poor outcome in childhood acute myeloid leukemia. Oncotarget 2014, 5, 2052-2064. [CrossRef] [PubMed]

104. Morvan, M.G.; Lanier, L.L. NK cells and cancer: You can teach innate cells new tricks. Nat. Rev. Cancer 2016, 16, 7-19. [CrossRef] [PubMed]

105. Zhang, J.; Han, X.; Hu, X.; Jin, F.; Gao, Z.; Yin, L.; Qin, J.; Yin, F.; Li, C.; Wang, Y. IDO1 impairs NK cell cytotoxicity by decreasing NKG2D/NKG2DLs via promoting miR-18a. Mol. Immunol. 2018, 103, 144-155. [CrossRef]

106. Häusler, S.F.; Montalbán del Barrio, I.; Strohschein, J.; Chandran, P.A.; Engel, J.B.; Hönig, A.; Ossadnik, M.; Horn, E.; Fischer, B.; Krockenberger, M.; et al. Ectonucleotidases CD39 and CD73 on OvCA cells are potent adenosine-generating enzymes responsible for adenosine receptor 2A-dependent suppression of T-cell function and NK cell cytotoxicity. Cancer Immunol. Immunother. 2011, 60, 1405-1418. [CrossRef] [PubMed]

107. Vago, L.; Perna, S.K.; Zanussi, M.; Mazzi, B.; Barlassina, C.; Stanghellini, M.T.; Perrelli, N.F.; Cosentino, C.; Torri, F.; Angius, A.; et al. Loss of mismatched HLA in leukemia after stem-cell transplantation. N. Engl. J. Med. 2009, 361, 478-488. [CrossRef] [PubMed]

108. Christopher, M.J.; Petti, A.A.; Rettig, M.P.; Miller, C.A.; Chendamarai, E.; Duncavage, E.J.; Klco, J.M.; Helton, N.M.; O'Laughlin, M.; Fronick, C.C.; et al. Immune escape of relapsed AML cells after allogeneic transplantation. N. Engl. J. Med. 2018, 379, 2330-2341. [CrossRef]

109. Damiani, D.; Tiribelli, M.; Raspadori, D.; Sirianni, S.; Meneghel, A.; Cavalllin, M.; Michelutti, A.; Toffoletti, E.; Geromin, A.; Simeone, E.; et al. Clinical impact of CD200 expression in patients with acute myeloid leukemia and correlation with other molecular prognostic factors. Oncotarget 2015, 6, 30212-30221. [CrossRef] 
110. Majeti, R.; Chao, M.P.; Alizadeh, A.A.; Pang, W.W.; Jaiswal, S.; Gibbs, K.D., Jr.; van Rooijen, N.; Weissman, I.L. CD47 is an adverse prognostic factor and therapeutic antibody target on human acute myeloid leukemia stem cells. Cell 2009, 138, 286-299. [CrossRef]

111. Zajac, M.; Zaleska, J.; Dolnik, A.; Bullinger, L.; Giannopoulos, K. Expression of CD274 (PD-L1) is associated with unfavourable recurrent mutations in AML. Br. J. Haematol. 2018, 183, 822-825. [CrossRef]

112. Wherry, E.J.; Kurachi, M. Molecular and cellular insights into T-cell exhaustion. Nat. Rev. Immunol. 2015, 15, 486-499. [CrossRef]

113. Kong, Y.; Zhang, J.; Claxton, D.F.; Ehmann, W.C.; Rybka, W.B.; Zhu, L.; Zeng, H.; Schell, T.D.; Zheng, H. PD-1(hi)TIM- $3^{+}$T-cells associate with and predict leukemia relapse in AML patients post allogeneic stem cell transplantation. Blood Cancer J. 2015, 5, e330. [CrossRef]

114. Mastaglio, S.; Wong, E.; Perera, T.; Ripley, J.; Blombery, P.; Smyth, M.J.; Koldej, R.; Ritchie, D. Natural killer receptor ligand expression on acute myeloid leukemia impacts survival and relapse after chemotherapy. Blood Adv. 2018, 2, 335-346. [CrossRef]

115. Nowbakht, P.; Ionescu, M.C.; Rohner, A.; Kalberer, C.P.; Rossy, E.; Mori, L.; Cosman, D.; De Libero, G.; Wodnar-Filipowicz, A. Ligands for natural killer cell-activating receptors are expressed upon the maturation of normal myelomonocytic cells but at low levels in acute myeloid leukemias. Blood 2005, 105, 3615-3622. [CrossRef]

116. Salih, H.R.; Antropius, H.; Gieseke, F.; Lutz, S.Z.; Kanz, L.; Rammensee, H.G.; Steinle, A. Functional expression and release of ligands for the activating immunoreceptor NKG2D in leukemia. Blood 2003, 102, 1389-1396. [CrossRef]

117. Zaretsky, J.M.; Garcia-Diaz, A.; Shin, D.S.; Escuin-Ordinas, H.; Hugo, W.; Hu-Lieskovan, S.; Torrejon, D.Y.; Abril-Rodriguez, G.; Sandoval, S.; Barthly, L.; et al. Mutations associated with acquired resistance to PD-1 blockade in melanoma. N. Engl. J. Med. 2016, 375, 819-829. [CrossRef]

118. Benci, J.L.; Xu, B.; Qiu, Y.; Wu, T.J.; Dada, H.; Twyman-Saint Victor, C.; Cucolo, L.; Lee, D.S.M.; Pauken, K.E.; et al. Tumor interferon signaling regulates a multigenic resistance program to immune checkpoint blockade. Cell 2016, 167, 1540-1554.e12. [CrossRef]

119. Gettinger, S.; Choi, J.; Hastings, K.; Truini, A.; Datar, I.; Sowell, R.; Wurtz, A.; Dong, W.; Cai, G.; Melnick, M.A.; et al. Impaired HLA Class I antigen processing and presentation as a mechanism of acquired resistance to immune checkpoint inhibitors in lung cancer. Cancer Discov. 2017, 7, 1420-1435. [CrossRef]

120. George, S.; Miao, D.; Demetri, G.D.; Adeegbe, D.; Rodig, S.J.; Shukla, S.; Lipschitz, M.; Amin-Mansour, A.; Raut, C.P.; Carter, S.L.; et al. Loss of PTEN is associated with resistance to anti-PD-1 checkpoint blockade therapy in metastatic uterine leiomyosarcoma. Immunity 2017, 46, 197-204. [CrossRef]

121. Rotolo, A.; Caputo, V.S.; Holubova, M.; Baxan, N.; Dubois, O.; Chaudhry, M.S.; Xiao, X.; Goudevenou, K.; Pitcher, D.S.; Petevi, K.; et al. Enhanced anti-lymphoma activity of CAR19-iNKT-cells underpinned by dual CD19 and CD1d Targeting. Cancer Cell 2018, 34, 596-610.e11. [CrossRef]

122. Guan, P.; Bassiri, H.; Patel, N.P.; Nichols, K.E.; Das, R. Invariant natural killer T-cells in hematopoietic stem cell transplantation: Killer choice for natural suppression. Bone Marrow Transplant. 2016, 51, 629-637. [CrossRef]

123. Hermanson, D.L.; Bendzick, L.; Pribyl, L.; McCullar, V.; Vogel, R.I.; Miller, J.S.; Geller, M.A.; Kaufman, D.S. Induced pluripotent stem cell-derived natural killer cells for treatment of ovarian cancer. Stem Cells 2016, 34, 93-101. [CrossRef]

124. Zeng, J.; Tang, S.Y.; Toh, L.L.; Wang, S. Generation of "Off-the-Shelf" Natural Killer Cells from Peripheral Blood Cell-Derived Induced Pluripotent Stem Cells. Stem Cell Reports 2017, 9, 1796-1812. [CrossRef]

(C) 2019 by the authors. Licensee MDPI, Basel, Switzerland. This article is an open access article distributed under the terms and conditions of the Creative Commons Attribution (CC BY) license (http://creativecommons.org/licenses/by/4.0/). 